\title{
PARADIGMA BARU KOMPETENSI ARSIPARIS DALAM MENGHADAPI ERA DIGITAL
}

\author{
Trina Nur Faturohmah \\ Universitas Indonesia \\ Email: trina.nur@ui.ac.id \\ Nina Mayesti \\ Universitas Indonesia \\ Email: nina.mayesti@ui.ac.id
}

\begin{abstract}
Abstrak:
Perkembangan teknologi dan informasi yang pesat membawa dunia pada perubahan dimana era ini ditandai dengan melimpahnya data dan informasi. Namun, kemajuan ini tidak serta merta memberi peluang yang mudah bagi arsiparis untuk berkembang. Pandangan profesi arsiparis saat ini masih kurang familiar di mata masyarakat Indonesia, oleh karenanya muncul tuntutan akan pengembangan kompetensi arsiparis atau kemampuan baru yang harus dimiliki untuk dapat beradaptasi dengan perkembangan ilmu pengetahuan serta teknologi informasi dan komunikasi saat ini. Jenis penelitian ini menggunakan pendekatan kualitatif deskriptif dengan metode literature review atau tinjauan pustaka. Ada tiga poin penting yang dibahas dalam artikel ini yaitu memahami kompetensi arsiparis, transformasi kearsipan di era digital, dan mempersiapkan kompetensi arsiparis dalam menghadapi era digital.
\end{abstract}

Kata kunci : kompetensi, arsiparis, transformasi, era digital.

\begin{abstract}
Abstrack:
The rapid development of technology and information has brought the world to a change where this era is marked by an abundance of data and information. However, these advances do not necessarily provide easy opportunities for archivists to develop. The current view of the archivist profession is still not familiar to the Indonesian people, therefore there is a demand for the development of archivist competencies or new abilities that must be possessed to be able to adapt to the current development of science and information and communication technology. This type of research uses a descriptive qualitative approach with a literature review method or literature review. There are three important points discussed in this article, namely understanding the competence of archivists, transforming archives in the digital era, and preparing archivists' competencies in facing the digital era.
\end{abstract}

Keywords: competence, archivist, transformation, digital age.

\section{Pendahuluan}

Perkembangan teknologi dan informasi sangat begitu pesat kemudian telah membawa dunia pada perubahan dimana era ini ditandai dengan melimpahnya data dan informasi hingga pengelolaan big data. Hal ini sangat berpengaruh kepada keahlian bagi pekerja informasi dan tidak menutup kemungkinan bagi arsiparis. Teknologi yang ada dan semakin berkembang saat ini, serta kemunculan berbagai sistem digital, juga dapat menjadi peluang bagi arsiparis dalam mengikuti dan memahami media digital untuk dapat menunjang eksistensi dan keberadaannya. Namun, kemajuan ini tidak serta merta memberi peluang yang mudah bagi arsiparis untuk berkembang. Pandangan profesi arsiparis saat ini masih kurang familiar di mata masyarakat Indonesia, pandangan sebelah mata tentang profesi arsiparis yang kurang diminati serta masih diremehkan karena hanya dianggap sebagai pengelola tumpukan kertas yang masih dipandang rendah. Menurut Widodo (2016) "keberadaan Arsiparis masih dilirik sebatas pekerja arsip menurut fungsinya tanpa ada kewenangan yang dimilikinya". ${ }^{1}$ Banyak anggapan 
bahwa pengelolaan arsip dapat dikelola oleh siapa saja sehingga organisasi maupun lembaga mengesampingkan profesi ini. Setelah ditinjau lebih mendalam apa yang menjadi persoalan tersebut terus berlarut-larut hingga era digital saat ini. Era yang merupakan segala aspek pekerjaan sampai personal branding viral yang diciptakan baik melalui media sosial maupun platform digital lain untuk mendobrak perubahan sesuai dengan keinginan dan tujuan dari masing-masing. Arsiparis merupakan seseorang yang mempunyai kompetensi yang meliputi beberapa aspek, pengetahuan, keterampilan, serta sikap (Perka ANRI Nomor 25 Tahun 2016$)^{2}$, teknologi yang berkembang justru dapat menjadi sarana bagi arsiparis dalam mengelola arsip dalam bentuk digital, baik dalam segi penyimpanan, layanan informasi bebasis digital, sampai kolaborasi terkait data digital antara lembaga informasi. Kompetensi Arsiparis dalam menghadapi era digital saat ini diharapkan dapat memunculkan sebuah paradigma baru di masa depan bagi wajah lembaga arsip yang akan datang, khususnya bagi arsiparis. Tuntutan akan adanya kemampuan dan skill yang baru yang harus dimiliki untuk dapat beradaptasi dengan perkembangan ilmu pengetahuan serta teknologi informasi dan komunikasi saat ini.

\section{Metode Penelitian}

Jenis penelitian ini menggunakan pendekatan kualitatif deskriptif dengan metode literature review atau tinjauan pustaka. Literature review merupakan suatu kegiatan yang berkenaan dengan metode pengumpulan data pustaka, membaca, merangkum serta mencatat hal-hal penting kemudian mengolah bahan koleksi tanpa harus

${ }^{1}$ Widodo, Bambang P. (2016). Sinergitas Antara Fungsi, Tugas, dan Kewenangan Arsiparis: Suatu Gagasan Konstruktif. Jurnal Kearsipan, Vol. 11 No. 12. Hal 39-50. Jakarta: Pusat Pengkajian dan Pengembangan Sistem Kearsipan ANRI.

${ }^{2}$ Peraturan Kepala Arsip Nasional Republik Indonesia Nomor 25 Tahun 2016. (2016). Pedoman Penyelenggaraan Pendidikan Dan Pelatihan Kearsipan.

${ }^{3}$ Zed, Mestika. 2004. Metode Penelitian Kepustakaan. Yayasan Bogor Indonesia: Jakarta. melakukan riset lapangan (Mustika, 2004). ${ }^{3}$ Literature review juga merupakan metode yang sistematis, eksplisit dan reprodusibel dalam melakukan identifikasi, evaluasi dan sintesis terhadap karya hasil penelitian dan pemikiran yang telah dihasilkan oleh para peneliti maupun praktisi (Okoli \& Schabram, 2010). ${ }^{4}$

Pengambilan data dalam penelitian ini melalui kajian literatur berupa buku, artikel dalam jurnal, peraturan perundang-undangan, dan sumbersumber tertulis lainnya yang sejalan dengan tujuan penelitian. Artikel-artikel dalam maupun luar negeri yang membahas tentang arsiparis dihimpun, kemudian dianalisis untuk lebih memahami konsep kesiapan arsiparis dalam menghadapi era digital, serta melakukan pencarian penelitian terdahulu mengenai kajian peran baru arsiparis.

\section{Hasil dan Pembahasan \\ Kompetensi Arsiparis}

Kompetensi dapat diartikan sebagai kewenangan (kekuasaan) dalam menentukan, memutuskan sesuatu, karena dengan adanya kompetensi kinerja seseorang dapat diketahui tingkat kredibilitasnya. Kompetensi Arsiparis pada dasarnya tidak hanya mengandalkan pada persoalan teknis, akan tetapi juga terkait dengan sikap profesional maupun perilaku. Sehingga Arsiparis dapat memiliki keterampilan maupun skill professional yang dapat terus berkembang untuk kedepannya. Perkembangan arus informasi yang kian pesat mengakibatkan kebutuhan setiap individu akan informasi kian bertambah, ini menjadi tantangan yang harus dihadapi profesi Arsiparis ke depan dalam memenuhi kebutuhan informasi masyarakat. Saat ini pandangan terhadap Arsiparis yang hanya dianggap sebagai pengelola kertas harus dapat diubah dengan meningkatkan kompetensi Arsiparis sebagai pengelola informasi.

Menurut Yakel dalam Kathleen (2010) dasar dari semua kegiatan arsiparis adalah dokumendokumen ini tidak boleh diubah oleh penggunaannya tetapi tetap tersedia untuk dipelajari oleh 
generasi mendatang, digunakan untuk mendapatkan wawasan baru, dan untuk membuat perbandingan lebih lanjut (respect des fonds). ${ }^{5} \mathrm{Mc}$ Ashan dalam Sutrisno (2011:203) mengemukakan kompetensi diartikan sebagai pengetahuan, keterampilan, dan kemampuan yang dikuasai oleh seseorang yang telah menjadi bagian dari dirinya, sehingga ia dapat melakukan perilaku perilaku kognitif, afektif, dan psikomotorik dengan sebaik baiknya. ${ }^{6}$ Oleh karena itu dibutuhkan SDM kearsipan yang profesional, mumpuni, dan bertanggung jawab atas kebenaran sejarah dengan menyelamatkan segala bentuk arsip, baik statis maupun dinamis (Mukaromah, 2013). ${ }^{7}$ Oleh sebab itu menurut Mangindaan dalam Handayani (2018) pemenuhan kebutuhan SDM kearsipan tidak dapat diisi oleh sembarang orang tetapi harus direncanakan, disiapkan, dan merupakan orang yang kompeten di bidangnya, bukan orang buangan. ${ }^{8}$ Dalam PP Nomor 28 Tahun 2012 Pasal 151 ayat (2) memberikan detail tentang fungsi dan tugas arsiparis. ${ }^{9}$ berikut uraian dari fungsi dan tugas arsiparis adalah:

1. menjaga terciptanya arsip dari kegiatan yang dilakukan oleh lembaga negara. pemerintahan daerah, lembaga pendidikan, perusahaan, organisasi politik, dan organisasi kemasyaraka$\tan$;

2. menjaga ketersediaan arsip yang autentik dan terpercaya sebagai alat bukti yang sah;

3. menjaga terwujudnya pengelolaan arsip yang andal dan pemanfaatan arsip sesuai dengan ketentuan peraturan perundang-undangan;

4. menjaga keamanan dan keselamatan arsip yang berfungsi untuk menjamin arsip-arsip yang berkaitan dengan hak-hak keperdataan rakyat melalui pengelolaan dan pemanfaatan

${ }^{4}$ Okoli, C., Schabram, K. (2010). A Guide to Conducting a Systematic Literature Review of Information Systems Research. Sprouts: Working Papers on Information Systems, 10(26).

${ }^{5}$ Marquis, Kathleen. (2010). "Not Dragon at the Gate but Research Partner: The Reference Archivist as Mediator", dalam Archives, Documentation, and Institutions of Social Memory: Essays from The Saywers Seminar, Francis X. Blouin Jr. and William G. Rosenberg, Eds. : p. 36-42. arsip yang autentik dan terpercaya;

5. menjaga keselamatan dan kelestarian arsip sebagai bukti pertanggungjawaban dalam kehidupan bermasyarakat, berbangsa; serta

6. menyediakan informasi guna meningkatkan kualitas pelayanan publik dalam pengelolaan dan pemanfaatan arsip yang autentik dan terpercaya.

Sedangkan Flexner mengemukakan 6 syarat untuk dapat disebut sebagai profesi. Adapun keenam syarat itu ialah:

1. Profesi merupakan pekerjaan intelektual artinya menggunakan intelegensinya secara bebas yang diterapkan pada masalah yang dihadapinya dengan tujuan memahami masalah, menguasainya, serta memecahkannya.

2. Profesi merupakan pekerjaan yang berasal dari ilmu pengetahuan dalam arti luas sehingga hasilnya dapat dipertanggungjawabkan secara ilmiah.

3. Profesi merupakan pekerjaan praktis artinya tidak selalu merupakan kajian teori akademis melainkan harus juga dapat diterapkan.

4. Profesi memiliki standar pelaksanaan serta tolak ukur keberhasilannya. Kompetensi Arsiparis.

5. Profesi merupakan pekerjaan yang berorientasi kepada jasa, artinya memberikan jasa untuk orang lain bukan untuk dirinya sendiri.

6. Profesi merupakan pekerjaan yang memiliki kode etik yang berlaku untuk kalangan sendiri. (Sulistyo-Basuki. 2003. 354.). ${ }^{10}$

Dalam Peraturan Kepala Anri Nomor 6 Tahun 2016 tentang Pedoman Sertifikasi Jabatan Fungsional Arsiparis ${ }^{11}$ menyebutkan bahwa kompetensi yang harus dimiliki oleh seorang arsiparis adalah sebagai berikut:

\section{Pengetahuan}

Aspek pengetahuan merupakan kompetensi dasar yang harus dimiliki oleh seorang arsiparis 
da 1 am me 1 akukan kegiatan kearsipan yang tidak hanya meliputi pengetahuan tentang pengelolaan arsip saja tapi juga keilmuan lainnya seperti sejarah, budaya, informasi dan teknologi, ekonomi serta ilmu lainnya yang mendukung tugas arsiparis.

\section{Keterampilan}

Seorang arsiparis juga harus memiliki keterampilan dalam pengelolaan, menempatakan, menemukan kembali arsip, dan memilah golongan arsip serta arsiparis juga harus memiliki keterampilan dalam menggunakan sarana prasarana sehingga dapat menyajikannya secara cepat dan tepat sesuai dengan kebutuhan.

\section{Sikap}

Arsiparis dituntut untuk memiliki sikap profesional yakni sabar, teliti, mandiri, bertanggung jawab serta memiliki peran aktif dalam menjalankan tugas kearsipan

Seorang arsiparis harus memiliki dan semangat integritas yang tinggi terhadap menjalankan profesinya. Bertanggung jawab terhadap pekerjaan yang dilakukannya mulai dari pemeliharaan dan pengelolaan arsip itu sendiri hingga pelayanan kepada masyarakat. hal ini pemeliharaan warisan budaya nasional guna kepentingan generasi sekarang dan masa yang akan datang. selain itu arsiparis harus mengembangakan kemampuan yang dimiliki sesuai dengan perkembangan teknologi informasi.

\section{Transformasi Kearsipan di Era Digital}

Kemajuan Teknologi Informasi dan teknologi (TIK) membawa perkembangan pada dunia digital

${ }^{6}$ Sutrisno, Edi. (2011). Manajemen Sumber Daya Manusia. Jakarta: Kencana.

${ }^{7}$ Mukaromah, S. (2013). Pengaruh penataan arsip dan kompetensi petugas arsip terhadap kualitas pelayanan pada sub bagian tata usaha di Kantor Kementerian Agama Kabupaten Demak. Jurnal Kearsipan. Retrieved from ejournal.ip.fisip-unmul.ac.id

${ }^{8}$ Handayani, F., \& Sari, R. (2018). Analisis Kompetensi Arsiparis Profesional di Indonesia. JIPI :Jurnal Ilmu Perpustakaan Dan Informasi, 3(2), 226-237. menjadi semakin cepat dan terus berevolusi pada berbagai sektor maupun bidang. Terutama pada bidang kearsipan yang juga akan terus mengalami perubahan yang dihasilkan dari perkembangan TIK. Dampak dari pengelolaan arsip secara elektronik adalah keterbukaan informasi yang akuntabel. Ini pula sesuai dengan RPJMN 20152019 bahwa arah kebijakan dan strategi pemerintah yaitu penerapan e-government untuk mendukung bisnis proses pemerintahan dan pembangunan melalui strategi kearsipan berbasis TIK (Sulistiyowati, 2018:8). ${ }^{12}$ Arsip yang selama ini dikelola secara manual, untuk saat ini tidak cukup dengan menyimpan arsip di mobile file. Tetapi, arsip tersebut harus dikelola secara digitalisasi. Pengelolaan arsip secara digital ini juga membutuhkan penyediaan hardware dan software yang mumpuni, banyaknya arsip yang disimpan mempengaruhi terhadap kapasitas penyediaan sistem tersebut. Proses digitasi ini juga harus dipayungi dengan regulasi yang jelas, tidak semua arsip yang disajikan dalam bentuk digital dapat diakses oleh siapa saja karena terdapat sifat arsip yang rahasia yang tidak dapat disebarluaskan.

Tuntutan keterbukaan informasi yang begitu kuat juga dilandasi oleh suatu pengalaman serta tatanan masa lalu dinilai kurang adanya transparansi sehingga dianggap suatu kekurangan. oleh karenanya keterbukaan informasi saat ini dibuka lebar informasi seakan-akan milik semua orang. trend yang terjadi pada masa lalu "informasi tertutup bagi publik kecuali yang dibuka", sekarang dibalik menjadi "informasi terbuka bagi publik kecuali yang tertutup". bahkan pada era sekarang keterbukaan informasi seolah-olah sudah dijadikan sebagai indikator akuntabilitas. Dalam UU Nomor 14 tahun 2008 tentang Keterbukaan Informasi Publik (KIP) pada pasal 7 ayat 1 bahwa badan publik wajib menyediakan, mem-

${ }_{9}^{9}$ Peraturan Pemerintah Nomor 28 Tahun 2012 tentang Pelaksanaan Undang Undang Nomor 43 Tahun 2009 tentang Kearsipan.

${ }^{10}$ Basuki-Sulistyo. (2003). Manajemen Arsip Dinamis. Jakarta: Gramedia Pustaka Utama. 
berikan dan. atau menerbitkan informasi publik yang berada dibawah kewenangannya kepada pemohon informasi publik, selain informasi yang dikecualikan sesuai dengan ketentuan. serta pada ayat 2 bahwa badan publik juga wajib menyediakan informasi publik yang akurat, benar dan tidak menyesatkan. ${ }^{13}$ Oleh karena itu Arsiparis dengan badan yang dikelolanya serta dengan bidang lainnya dalam keterbukaan informasi publik harus mampu bekerjasama melakukan penyediaan, pengelolaan, pengamanan serta pelayanan informasi dengan berbagai transaksi organisasi. Ini menjadi satu langkah yang bagus yang tidak hanya dalam kompetensi Arsiparis yang menjadi peningkatan yang sangat signifikan, akan tetapi juga akan terwujudnya suatu layanan informasi yang baik dan terintegrasi. Oleh karenanya UU KIP ini dapat menjadi salah satu payung hukum yang kuat bagi Arsiparis untuk ikut dalam pelayanan informasi publik sebagai implementasi keterbukaan informasi.

Sehingga pada akhirnya sistem pengelolaan arsip yang ada mampu secara digital dapat menjadi sarana setiap lembaga berintegrasi tidak hanya pada satu lini sektor atau bidang, namun dapat terintegrasi ataupun linked open data dengan sistem-sistem yang tergabung menjadi satu kesatuan informasi yang dapat diakses dengan terhubung ke berbagai sumber maupun yang tergabung dalam GLAM (gallery, library, archive, museum) untuk sharing atau linked open data agar semua informasi terkait satu objek atau subjek dapat diperoleh dari berbagai lembaga yang mengelola. Linked open data juga dapat menciptakan kolaborasi untuk pertukaran data yang terkait antara GLAM. Data yang dipublikasikan dari masing-masing lembaga informasi khusus-

${ }^{11}$ Peraturan Kepala Arsip Nasional Republik Indonesia Nomor 6 Tahun 2016. (2016). Pedoman Sertifikasi Jabatan Fungsional Arsiparis

${ }^{12}$ Sulistiyowati. (2018). Penyelenggaraan Kearsipan di Lingkungan Pemerintahan [makalah]. Surabaya, 28 Maret 2018.

${ }^{13}$ Undang Undang Republik Indonesia Nomor 14 Tahun 2008 tentang Keterbukaan Informasi Publik. UU 14 Tahun 2008.rtf (kpk.go.id)

${ }^{14}$ Llanes-Padrón, D., \& Pastor-Sánchez, J. A. (2017). Records in contexts: the road of archives to semantic interoperability. Program, 51(4), 387-405. https://doi.org/10.1108/PROG-03-2017-0021 nya kearsipan adalah data yang sifatnya dapat dikonsumsi untuk umum terlebih dalam bidang kearsipan terdapat data rahasia dan hak akses dari arsip. Hidalgo (2016) dalam Records in Contexts: the road of archives to semantic interoperability juga menjelaskan bahwa The reuse of controlled vocabularies (authorities, subject headings, classifications, thesauruses) allows for far more efficient descriptions of bibliographical and archival resources. The publication of datasets according to the Linked Open Data principles provides great potential for the reuse and conservation of cultural heritage in general and archives in particular. ${ }^{14}$ Publikasi kumpulan data sesuai dengan prinsip Linked Open Data ini memberikan potensi besar untuk penggunaan kembali dan konservasi warisan budaya pada umumnya dan arsip pada khususnya tentunya dengan disertai dengan pendeskripsian bibliografi arsip yang efektif dan efisien. Kolaborasi antar lembaga terkait penyediaan data bersama ini tentunya dapat memastikan pelestarian jangka panjang, data yang dipublikasikan memudahkan dalam penggunaan kembali sebagai bahan konsultasi baik bagi individu seperti peneliti maupun kelompok seperti lembaga.

\section{Mempersiapkan Kompetensi Arsiparis da- lam Menghadapi Era Digital}

Perkembangan arus informasi yang kian pesat mengakibatkan kebutuhan setiap individu akan informasi kian bertambah, ini menjadi tantangan yang harus dihadapi profesi Arsiparis ke depan dalam memenuhi kebutuhan informasi masyarakat. Saat ini pandangan terhadap Arsiparis yang hanya dianggap sebagai pengelola kertas harus dapat diubah dengan meningkatkan kompetensi Arsiparis sebagai pengelola informasi. Dalam mempersiapkan kompetensi Arsiparis dalam menghadapi Era Digital ini, tentunya

${ }^{15}$ Handoko, H, T (2012) ManajemenPersonalia dan Sumber Daya Manusia. Yogyakarta: BPFE.

${ }^{16}$ Aulia'Rachman, M. (2018). Kecenderungan Baru Peran Arsiparis Kajian Di Kantor Arsip Universitas Indonesia. Jurnal Kearsipan, 13, 121-138. 
harus ada kerjasama antara Lembaga dan Arsiparis dalam memenuhi peningkatan kompetensi dan keterampilan Arsiparis. Agar sebuah lembaga memiliki arsiparis yang berkompeten di era digital saat ini adalah dengan memberikan ilmu kepada arsiparis dalam bidang teknologi. Menurut Handoko (2012) mengatakan faktor-faktor lingkungan dalam keputusan personalia salah satunya adalah teknologi. ${ }^{15}$ Teknologi menjadi faktor yang paling berpengaruh. Jika arsiparis kompeten dalam pengelolaan arsip secara manual dan elektronik akan tumbuh keseimbangan. Lembaga sangat perlu untuk meningkatkan sumber daya manusia dalam bidang TIK bagi arsiparis melalui pelatihan atau workshop elektronik arsip. Sehingga, arsip yang dikelola dapat diselamatkan pula melalui digitalisasi kearsipan.

Seperti dalam penelitian yang dilakukan Margareta (2018) yang berjudul Kecenderungan baru peran arsiparis yang dilakukan di kantor arsip Universitas Indonesia yang menghasilakan salah satu peran baru arsiparis saat ini yaitu sebagai arsiparis digital. ${ }^{16}$ Arsiparis digital dalam penelitian tersebut bermakna bahwa arsiparis dapat melakukan pengorganisasian arsip yang media dan formatnya dalam bentuk digital atau elektronik. Arsiparis tersebut bertanggung jawab terhadap data digital milik organisasi, serta dapat menciprakan tata kelola arsip elektronik yang baik dan efisien.

\section{Kesimpulan dan Saran}

Pada era digital ini Arsiparis dihadapkan oleh berbagai persoalan yang semakin kompleks dalam pengelolaan arsip maupun tantangan dalam dirinya sebagai Arsiparis yang mampu beradaptasi dan bertransformasi menjadi diri yang mampu berkompeten dalam bidangnya maupun kompeten pada sisi yang mampu meningkatkan eksistensi dari seorang arsiparis. dimana saat ini perubahan akan terus terjadi baik dalam kompetensi diri maupun kegiatan pengelolaan arsip di era digital. Arsiparis harus mampu beradaptasi dengan perkembangan teknologi dan informasi, sehingga paradigma arsiparis yang terbelakang dapat berubah.

Dukungan dari berbagai pihak juga diperlukan, seperti dari lembaga yang menaungi. Lembaga dapat memberikan pelatihan untuk pengembangan kompetensi arsiparis di era digital, selain memberikan pelatihan lembaga juga harus dapat memberikan dukungan berupa penyediaan teknologi yang dapat digunakan oleh arsiparis dalam meningkatkan layanan kearsipan digital. Kolaborasi antar lembaga juga diperlukan, agar dapat memaksimalkan penyajian data yang terhubung antar lembaga sehingga dapat memudahkan dapat kegiatan penelitian atau pelestarian arsip. Dengan mempersiapkan kompetensi arsiparis di era digital ini, diharapkan dapat menjadi modal dalam eksistensi dunia kearsipan sehingga tidak tertinggal dari lembaga layanan informasi lainnya.

\section{Referensi}

Afrilia, A. M. (2018). Personal Branding Remaja di Era Digital. Mediator: Jurnal Komunikasi, 11(1), 20-30. https://doi.org/10.29313/mediator.v11i1.3626

Asmiyanto, T. (2019). Metamorphosis archivist in the Industrial Age 4.0: A challenge in the face of digital revolution. Record and Library Journal, 5(1), 12-21. https://e-journal.unair.ac.id/ index.php/RLJ

Basuki-Sulistyo. (2003). Manajemen Arsip Dinamis. Jakarta: Gramedia Pustaka Utama

Handayani, F., \& Sari, R. (2018). Analisis Kompetensi Arsiparis Profesional di Indonesia. JIPI :Jurnal Ilmu Perpustakaan Dan Informasi, 3(2), 226-237.

Llanes-Padrón, D., \& Pastor-Sánchez, J. A. (2017). Records in contexts: the road of archives to semantic interoperability. Program, 51(4), 387-405. https://doi.org/10.1108/ PROG-03-2017-0021

Marquis, Kathleen. (2010). "Not Dragon at the Gate but Research Partner: The Reference 
Archivist as Mediator", dalam Archives, Documentation, and Institutions of Social Memory: Essays from The Saywers Seminar, Francis X. Blouin Jr. and William G. Rosenberg, Eds.: p. 36-42.

Okoli, C., Schabram, K. (2010). A Guide to Conducting a Systematic Literature Review of Information Systems Research. Sprouts: Working Papers on Information Systems, 10(26).

Peraturan Kepala Arsip Nasional Republik Indonesia Nomor 6 Tahun 2016. (2016). Pedoman Sertifikasi Jabatan Fungsional Arsiparis

Peraturan Kepala Arsip Nasional Republik Indonesia Nomor 25 Tahun 2016. (2016). Pedoman Penyelenggaraan Pendidikan Dan Pelatihan Kearsipan. https://jdih.anri.go.id/peraturan/ Perka_25_2016.pdf
Peraturan Pemerintah Nomor 28 Tahun 2012 tentang Pelaksanaan UndangUndang Nomor 43 Tahun 2009 tentang Kearsipan

Rachman, M. A. (2018). Kecenderungan Baru Peran Arsiparis Kajian di Kantor Arsip Universitas Indonesia. Jurnal Kearsipan, 121-138.

Undang Undang Republik Indonesia Nomor 14 Tahun 2008 tentang Keterbukaan Informasi Publik. UU 14 Tahun 2008.rtf (kpk.go.id)

Mukaromah, S. 2013. Pengaruh penataan arsip dan kompetensi petugas arsip terhadap kualitas pelayanan pada sub bagian tata usaha di Kantor Kementerian Agama Kabupaten Demak. Jurnal Kearsipan. Retrieved from ejournal.ip.fisip-unmul.ac.id

Sulistiyowati. (2018). Penyelenggaraan Kearsipan di Lingkungan Pemerintahan [makalah]. Surabaya, 28 Maret 2018. 